\title{
Enhancement of Bovine Oocyte Maturation by Leptin is Accompanied by an Upregulation in mRNA Expression of Leptin Receptor Isoforms in Cumulus Cells
}

\author{
HELENA T.A. vAN TOL,* FRANK J.C.M. vAN EERDENBURG, BEN COLENBRANDER, \\ AND BERNARD A.J. ROELEN \\ Department of Farm Animal Health, Faculty of Veterinary Medicine, Utrecht University, Utrecht, The Netherlands
}

\begin{abstract}
In this study, the mechanisms of supposed leptin action on oocyte maturation were examined. Expression of leptin mRNA, as determined with RT-PCR, was present in oocytes but not in cumulus cells. The long isoform of the leptin receptor $(\mathrm{ObR}-\mathrm{L})$ was expressed exclusively in cumulus cells after 7 and $23 \mathrm{hr}$ of maturation. In oocytes the expression of the short receptor isoform (ObR-S) and all the receptor isoforms combined (ObR-T) did not change during maturation, as determined by quantitative RT-PCR, but in cumulus cells there was a significant increase in ObR-S transcripts after $7 \mathrm{hr}$ of maturation. To determine if leptin plays a role in resumption of meiosis, oocytes meiotically arrested by the connection of the cumulus to a piece of granulosa layer were exposed to leptin. After $23 \mathrm{hr}$ of culture, the proportion of oocytes that had resumed meiosis did not differ from the control. Exposure of COCs to leptin $(1,000 \mathrm{ng} / \mathrm{ml})$ resulted after $17 \mathrm{hr}$ of maturation in a smaller proportion of oocytes that was still in metaphaseI stage (M-I) compared to the control group. Fertilization of oocytes after maturation in the presence of leptin resulted in a larger proportion of embryos that had developed to the 8-cell stage on Day 5 compared to the control group and in more blastocysts on Day 8 of culture. It is concluded that leptin enhances meiotic maturation of bovine oocytes, and that this effect is cumulus cell-mediated. Mol. Reprod. Dev. 75: 578587, 2008. ๑ 2007 Wiley-Liss, Inc.
\end{abstract}

Key Words: leptin; receptor; bovine; oocyte maturation; quantitative $\mathrm{RT}$ T-PCR

\section{INTRODUCTION}

Leptin, a 16-kDa peptide hormone of the obese gene, is secreted primarily in adipocytes and is known to play a critical role in the regulation of body weight by inhibiting food intake and stimulating energy expenditure (Zhang et al., 1994).

Apart from a role in the regulation of body weight and energy expenditure, evidence suggests that leptin also plays an important role in female reproduction. Mutant female mice lacking leptin (ob/ob) are both obese and infertile and where diet restriction has no effect on fertility, treatment with exogenous leptin restores fertility indicating a role of leptin on reproduction either through a neural cascade resulting in release of $\mathrm{GnRH}$ or through a direct action in the ovary (Barash et al., 1996; Chehab et al., 1996). In addition to its expression in adipocytes, leptin, and its mRNA have also been detected in oocytes and cumulus cells of several mammalian species (Antczak and Van Blerkom, 1997; Cioffi et al., 1997; Ryan et al., 2002; Craig et al., 2004).

The leptin receptor $(\mathrm{ObR})$ is a member of the class I cytokine receptor superfamily, and alternative splicing of the $3^{\prime}$ terminal results in six isoforms (Lee et al., 1996). The long transmembrane isoform (ObR-b) is highly expressed in the key nuclei of the hypothalamus and is thought to mediate most of the leptin signaling through both the signal transducer and activator of transcription 3 (STAT3) and mitogen-activated protein kinase (MAPK) pathways. The other transmembrane isoforms, ObR-a, c, d, and f, are more widely expressed and have short cytoplasmic domains with a janus kinase box that allows them to act through the MAPK pathway only (Bjorbaek et al., 1997; Tartaglia, 1997). ObR-e lacks both transmembrane and cytoplasmic domains, is soluble and serves as a leptin-binding protein (Yang et al., 2004).

Leptin receptor mRNA and protein have been detected in oocytes (Ryan et al., 2002; Cervero et al., 2004) and ovarian cells of several species (Cioffi et al., 1997; Zamorano et al., 1997; Spicer and Francisco, 1998; Lin et al., 2000; Ruiz-Cortes et al., 2000), suggesting that the oocyte is capable of direct or indirect response to leptin. Indeed, it has been shown that in vitro leptin induces resumption of meiosis in follicle-enclosed oocytes (Ryan et al., 2002) and that the presense of leptin in the maturation medium of cumulus oocyte complexes (COCs)

*Correspondence to: Helena T.A. van Tol, Department of Farm Animal Health, Faculty of Veterinary Medicine, Utrecht University, Yalelaan 104, 3584CM Utrecht, The Netherlands.

E-mail: H.T.A.vanTol@vet.uu.nl

Received 9 March 2007; Accepted 7 May 2007

Published online 20 September 2007 in Wiley InterScience (www.interscience.wiley.com).

DOI $10.1002 / \mathrm{mrd} .20801$ 
positively affects the developmental competence of these oocytes (Craig et al., 2004; Boelhauve et al., 2005).

A role of leptin during oocyte maturation by activating the STAT3 signal transduction pathway is suggested by Matsuoka et al. (1999) who found that stimulation of mouse (metaphase-II stage, M-II) oocytes with leptin caused phosphorylation of STAT3, but Craig et al. (2004) showed that the presence of leptin in maturation medium of porcine oocytes resulted in increased MAPK phosphorylation, while leptin-stimulated oocyte maturation was suppressed when MAPK phosphorylation was prevented with specific MAPK inhibitors. Furthermore, it has been suggested that leptin signaling through the STAT3 pathway is not required for reproduction since mice with disrupted ObR-b STAT3 signaling are obese yet fertile (Bates et al., 2003).

Since these findings suggest a paracrine or autocrine function of leptin in oocyte maturation, the mRNA expression of leptin and its receptor isoforms were examined in bovine oocytes and cumulus cells. Furthermore, the nuclear and cytoplasmic maturation of oocytes in the presence of leptin was investigated. This study demonstrates that expression levels of ObR-a and ObR-b in cumulus cells increase dramatically during oocyte maturation and that the presence of leptin during oocyte maturation accelerates the progression of meiosis. Also the cytoplasmic maturation is improved by the presence of leptin during maturation as indicated by enhanced blastocyst formation.

\section{MATERIALS AND METHODS}

\section{Collection and Culture of COCs and COCGs}

Bovine ovaries were collected at a slaughterhouse and transported to the laboratory within $2 \mathrm{hr}$ of slaughter. Antral follicles between 2 and $8 \mathrm{~mm}$ were aspirated by means of a suction pump under low vacuum. The follicular aspirates were pooled in a conical tube and allowed to settle for $15 \mathrm{~min}$. The sediment contained COCs connected to pieces of the membrana granulosa (COCG) and COCs without membrana granulosa. COCGs with an area of at least $0.25 \mathrm{~mm}^{2}$ of compact membrana granulosa and oocytes surrounded by a compact multilayered cumulus investment were selected from the follicular fluid, separated, washed three times in HEPES buffered M199 (Gibco BRL, Paisley, UK), and randomly allocated in groups of 12 COCGs or 35$60 \mathrm{COCs}$ per well in four-well culture plates (Nunc A/S, Roskilde, Denmark). Culture was carried out in $500 \mu \mathrm{l}$ M199 per well supplemented with $26.2 \mathrm{mM} \mathrm{NaHCO}_{3}$ (defined as M199) at $39^{\circ} \mathrm{C}$ in a humidified atmosphere of $5 \% \mathrm{CO}_{2}$ in air. Recombinant rat leptin was purchased from Sigma Chemical Co. (St. Louis, MO).

\section{RNA Extraction and cDNA Synthesis}

After maturation in the presence of $0.05 \mathrm{IU} / \mathrm{ml}$ recombinant human FSH [FSH-Org 32489, a kind gift from Dr. R. Hanssen (Organon, Oss, The Netherlands)], cumulus cells were separated from the oocytes using a narrow-bore Pasteur pipette. Denuded oocytes and cumulus cells were rinsed in PBS and stored at $-80^{\circ} \mathrm{C}$ until RNA extraction. RNA isolation and RT-PCR were performed on 45-92 denuded oocytes and their corresponding cumulus cells.

Isolation of total RNA was performed using the Invisorb ${ }^{\circledR}$ Spin Cell RNA Mini Kit (Invitek $\mathrm{GmbH}$, Berlin, Germany) as per the manufacturer's instructions. In short, each sample was lysed in $700 \mu$ lysis buffer and applied to the DNA-binding spin filter. After incubation and centrifugation, the RNA containing lysate was diluted (1:1) with $70 \%$ ethanol and pipetted directly onto a RNA-binding filter. The column was washed five times, followed by elution with $33 \mu \mathrm{l}$ RNAsefree water.

Reverse transcription (RT) was performed in a total volume of $40 \mu \mathrm{l}$ made up of $20 \mu \mathrm{l}$ of the sample RNA, $8 \mu \mathrm{l}$ of $5 \times$ RT buffer (Invitrogen, Breda, The Netherlands), 16 U RNAsin (Promega, Leiden, The Netherlands), 300 U Superscript II reverse transcriptase (Invitrogen), $1.2 \mu \mathrm{g}$ of random primers (Invitrogen) and containing final concentrations of $10 \mathrm{mM}$ DTT (Invitrogen) and $0.5 \mathrm{mM}$ of each dNTP (Promega). The mixture was incubated $5 \mathrm{~min}$ at $70^{\circ} \mathrm{C}, 1 \mathrm{hr}$ at $42^{\circ} \mathrm{C}$ followed by $5 \mathrm{~min}$ at $80^{\circ} \mathrm{C}$, before being stored at $-20^{\circ} \mathrm{C}$. Minus RT blanks were prepared from $10 \mu \mathrm{l}$ of the sample RNA under the same conditions but without the addition of reverse transcriptase.

\section{PCR Primer Design}

Primers used for both RT-PCR and quantitative RTPCR (QRT-PCR) procedures are summarized in Table 1. Primer pairs were designed (Primer Designer version 2.0, Scientific \& Educational Software, Cary, NC) using the bovine coding sequences, whereby preferably each primer of a pair was located on a separate gene exon.

A standard sequencing procedure (ABI PRISM 310 Genetic analyzer, Applied Biosystems, Foster City, CA) was used to verify the specificity of the PCR products of all target genes.

\section{Qualitative PCR}

PCR amplification was carried out in $200 \mu \mathrm{l}$ tubes (Biozym, Landgraaf, The Netherlands) using $1 \mu \mathrm{l}$ 1 cDNA as template in $25 \mu \mathrm{l}$ PCR mixture containing final concentrations of $2 \mathrm{mM} \mathrm{MgCl}_{2}, 200 \mu \mathrm{M}$ of each dNTP, $0.5 \mu \mathrm{M}$ each of primers, and $0.625 \mathrm{U}$ Taq DNA polymerase (HotStarTaq, Qiagen, Valencia, CA) in $1 \times$ PCR buffer (Qiagen).

The thermal cycling profile was as follows: initial denaturation and activation of the polymerase at $94^{\circ} \mathrm{C}$ for $15 \mathrm{~min}$, followed by 40 (ObR-L) or 45 (leptin) cycles of $15 \mathrm{sec}$ at $94^{\circ} \mathrm{C}, 30 \mathrm{sec}$ at the primer specific annealing temperature (see Table 1), and $45 \mathrm{sec}$ at $72^{\circ} \mathrm{C}$. Final extension was performed at $72^{\circ} \mathrm{C}$ for $10 \mathrm{~min}$.

Nesting was used for the amplification of ObR-L. For this second round of amplification $1 \mu \mathrm{l}$ of the first round product was transferred to another $200 \mu$ l tube containing $24 \mu \mathrm{l}$ reaction mixture as above, but with a different 
TABLE 1. Details of Primers Used for RT-PCR

\begin{tabular}{|c|c|c|c|c|c|}
\hline Target gene & Primer sequence $\left(5^{\prime} \rightarrow 3^{\prime}\right)$ & Sense $^{a}$ & Position & $\begin{array}{l}\text { Anneal temperature } \\
\qquad\left({ }^{\circ} \mathbf{C}\right)\end{array}$ & $\begin{array}{c}\text { Genbank } \\
\text { accession no. }\end{array}$ \\
\hline \multirow[t]{2}{*}{ ObR-T } & TCTTACGTGGAGGCTGTGC & $\mathrm{s}$ & $92-111$ & \multirow[t]{2}{*}{56} & \multirow[t]{2}{*}{ U83512 } \\
\hline & GGAGGTTCTCCAGGTCATTG & as & $280-299$ & & \\
\hline \multirow[t]{2}{*}{ ObR-S } & CCCAATATTTACGGAAGGAG & $\mathrm{s}$ & $2436-2455$ & \multirow[t]{2}{*}{58} & \multirow[t]{2}{*}{$\mathrm{AB} 207254$} \\
\hline & CAAAGAATGTCCGTTCTCTT & as & $2668-2687$ & & \\
\hline \multirow[t]{4}{*}{ ObR-L } & ACACCAGCATGATGCAGATC & $\mathrm{s}$ & $2502-2521$ & \multirow[t]{2}{*}{62} & \multirow[t]{4}{*}{ AB199589 } \\
\hline & GTTCATCCAGGCCTTCTGAG & as & $3159-3178$ & & \\
\hline & CAAACCCCAAGAACTGTTCC & $\mathrm{s}$ & $2624-2643$ & 62 & \\
\hline & TCTGTAGTTGCTGGCACCAT & as & $2797-2816$ & & \\
\hline \multirow[t]{2}{*}{ Leptin } & TCTTACGTGGAGGCTGTGC & $\mathrm{s}$ & $49-67$ & \multirow[t]{2}{*}{62} & \multirow[t]{2}{*}{ NM_173928 } \\
\hline & GGAGGTTCTCCAGGTCATTG & as & $294-313$ & & \\
\hline \multirow[t]{2}{*}{ ß-Actin } & TTACAACGAGCTGCGTGTGG & $\mathrm{s}$ & $42-61$ & \multirow[t]{2}{*}{59} & \multirow[t]{2}{*}{ K00622 } \\
\hline & TGGCAGGAGTGTTGAACGTC & as & $147-166$ & & \\
\hline \multirow[t]{2}{*}{ GAPDH } & AGGCATCACCATCTTCCAG & $\mathrm{s}$ & $179-198$ & \multirow[t]{2}{*}{61} & \multirow[t]{2}{*}{ AJ000039 } \\
\hline & GGCGTGGACAGTGGTCATAA & as & $485-504$ & & \\
\hline \multirow{2}{*}{ Ubiquitin } & CTGACCGGCAAGACCATCAC & $\mathrm{s}$ & $140-159$ & \multirow[t]{2}{*}{61} & \multirow{2}{*}{ AF506969 } \\
\hline & AGATGAGCCTCTGCTGGTCG & as & $232-251$ & & \\
\hline \multirow{2}{*}{$\begin{array}{l}\text { Ribosomal RNA } \\
\quad \text { (rRNA) }\end{array}$} & GGCTACCACATCCAAGGAAG & $\mathrm{s}$ & $62-81$ & \multirow[t]{2}{*}{61} & \multirow[t]{2}{*}{ AF176811 } \\
\hline & TCCAATGGATCCTCGCGGAA & as & $191-210$ & & \\
\hline \multirow{2}{*}{$\begin{array}{l}\text { Phosphoglycerokinase } \\
\text { (PGK) }\end{array}$} & CTGGACAAGCTGGATGTGAA & $\mathrm{s}$ & $72-91$ & \multirow[t]{2}{*}{61} & \multirow[t]{2}{*}{ ВT021601 } \\
\hline & AACAGCAGCCTTGATCCTCT & as & $160-179$ & & \\
\hline \multirow{2}{*}{$\begin{array}{l}\text { Ribosomal protein } \\
\text { L15 (RPL-15) }\end{array}$} & CACAAGTTCCACCACACTATTGG & $\mathrm{s}$ & $321-343$ & \multirow[t]{2}{*}{61} & \multirow[t]{2}{*}{ AY786141 } \\
\hline & TGGAGAGTATTGCGCCTTCTC & as & $365-385$ & & \\
\hline
\end{tabular}

${ }^{\mathrm{a}} \mathrm{s}$ and as refer to sense and anti-sense primer, respectively.

primer pair and amplified for 30 cycles according to the same profile.

After completion of the reaction, $10 \mu \mathrm{l}$ of the product was resolved on a $1 \%$ agarose gel containing $0.4 \mu \mathrm{g} / \mathrm{ml}$ ethidium bromide. A 100 basepair (bp) ladder was included as a reference for fragment size.

\section{Quantitative RT-PCR}

QRT-PCR was performed in triplo on three replicates of cDNA and singular on the -RT blanks. For each target gene all the samples were quantified simultaneously in one run in a 96 -well plate using a real-time PCR detection system (MyiQ Single-color Real-Time PCR Detection System; Bio-Rad Laboratories, Hercules, CA). Standard curves used to quantify the target genes ObR-T and ObR-S were 10-fold serial dilutions of known amounts of target gene PCR product. For quantification of the reference genes the standard curves consisted of 10 -fold serial dilutions of cDNA from $100 \mathrm{COCs}$ synthesized as described above.

The QRT-PCR reaction mixture $(25 \mu \mathrm{l})$ contained $1 \mu \mathrm{l}$ (target genes) or $0.1 \mu \mathrm{l}$ (reference genes) cDNA, $0.4 \mathrm{mM}$ of each primer (Isogen Bioscience BV, Maarssen, The Netherlands) and $12.5 \mu$ l of $\mathrm{IQ}^{\mathrm{TM}} \mathrm{Sybr}^{\circledR}$ Green Supermix (Bio-Rad Laboratories). After an initial denaturation step at $95^{\circ} \mathrm{C}$ for $3 \mathrm{~min}, 40$ cycles were carried out consisting $95^{\circ} \mathrm{C}$ for $15 \mathrm{sec}$, the primer specific annealing temperature (see Table 1) for $30 \mathrm{sec}$, and $72^{\circ} \mathrm{C}$ for $45 \mathrm{sec}$. To determine the purity of the product after amplification, melting curves were plotted.

The provided application software produced standard curves by plotting the log of the starting amount versus the threshold cycle for detection. The standard curves were subsequently used to calculate the relative starting quantity for each experimental sample by interpolation.

\section{SDS-PAGE and Western Blot Analysis}

After culture, COCs were collected, washed in PBS and an average of 250 COCs were lysed in $125 \mu \mathrm{l}$ RIPA buffer [1\% Nonidet P-40, $0.5 \%$ sodium deoxycholate, $0.1 \%$ SDS, $0.004 \%$ sodium azide, $1 \%$ PMSF solution, $1 \%$ protease inhibitor solution, $1 \%$ sodium orthovanadate solution in TBS (Santa Cruz Biotechnology, Santa Cruz, CA)] at $4^{\circ} \mathrm{C}$ for $30 \mathrm{~min}$.

Lysates were diluted 1:3 in sample buffer $(62.5 \mathrm{mM}$ Tris, $2 \%$ SDS, $0.1 \%$ glycerol, $0.05 \%$ ß-mercaptoethanol, and $0.006 \%$ bromophenol blue), boiled for $5 \mathrm{~min}$, aliquoted in $20 \mu \mathrm{l}$ portions and stored at $-20^{\circ} \mathrm{C}$ until use.

Samples and a positive control (human whole cell lysate; epitheliod carcinoma cells induced with IFN- $\gamma$ ) were separated on $11 \%$ SDS-polyacrylamide gels, and transferred onto nitrocellulose membranes (TransBlot $^{\mathbb{R}}$, Bio-Rad Laboratories). The membranes were rinsed in TBS-Tween [TBS with $0.05 \%$ Tween-20 (ICN, Aurora, OH)] and blocked with 5\% nonfat dry milk in TBS-Tween (blocking buffer) for $1 \mathrm{hr}$, followed by overnight incubation at $4{ }^{\circ} \mathrm{C}$ with a polyclonal antibody against human $\beta$-actin (sc-1616; Santa Cruz Biotechnology), a polyclonal antibody against human p-STAT3 (sc-7993-R; Santa Cruz Biotechnology), or a polyclonal antibody against human p-ERK (sc-7976-R; Santa Cruz Biotechnology) diluted respectively 1:1,000, 1:500, and 1:500 in blocking buffer. After three washing steps, the membranes were incubated for $1 \mathrm{hr}$ at RT with horseradish peroxidase (HRP) conjugated rabbit anti-goat 
IgG (sc-2768; Santa Cruz Biotechnology; ß-actin) or with HRP-conjugated goat anti-rabbit IgG (31460; Pierce Biotechnology, Rockford, IL; p-STAT3 and p-ERK) diluted 1:10,000 in blocking buffer.

Subsequently, the membranes were washed four times in TBS-Tween and once in TBS followed by visualization of the antibody-protein complexes using Immun-Star ${ }^{\circledR}$ chemiluminescent substrate (Bio-Rad Laboratories) and exposure to X-ray film (Fuji, Dusseldorf, Germany). As a control for antibody specificity, antibodies were also preincubated for $1 \mathrm{hr}$ with a $5 \times$ weight excess of the respective peptide used for immunization.

\section{Assessment of the Nuclear Stage}

After culture the oocytes originating from COCs and COCGs were denuded by vortexing for $3 \mathrm{~min}$ whereafter they were recovered and transferred to glass slides. Vaseline was used to maintain the coverslip in contact with the oocytes without excessive pressure. For fixation the slides were immersed in ethanol/acetic acid (3:1) for at least $24 \mathrm{hr}$. The oocytes were stained in 1\% acetoorcein and examined under a light microscope at $100 \times$ magnification. Oocytes were classified as germinal vesicle $(\mathrm{GV})$, metaphase-I (M-I; from GV breakdown up to metaphase-I plate) or M-II (from anaphase-I up to metaphase-II plate).

\section{In-Vitro Fertilization and Embryo Culture}

After $23 \mathrm{hr}$ of maturation groups of 35 COCs were fertilized in vitro according to the procedure described by Parrish et al. (1988) with small modifications (Izadyar et al., 1996). Per well, sperm cells were added to a final concentration of $0.5 \times 10^{6}$ cells $/ \mathrm{ml}$, in addition to $20 \mu \mathrm{l}$ heparin (final concentration $10 \mu \mathrm{g} / \mathrm{ml}$ ), and $20 \mu \mathrm{l}$ PHE (containing $20 \mu \mathrm{M}$ d-penicillamine, $10 \mu \mathrm{M}$ hypotaurine, $1 \mu \mathrm{M}$ epinephrine). After $20 \mathrm{hr}$ of incubation, the cumulus cells were removed from presumptive zygotes by vortexing for $3 \mathrm{~min}$. Ten presumptive zygotes were randomly placed in a $20 \mu \mathrm{l}$ droplet of synthetic oviductal fluid (SOF) medium supplemented with essential and nonessential amino acids and $0.1 \%(\mathrm{w} / \mathrm{v})$ BSA. The drops of SOF medium were covered with mineral oil (Reproline medical GmBH, Rheinbach,
Germany) and incubation took place at $39^{\circ} \mathrm{C}$ in an humidified atmosphere with $7 \% \mathrm{O}_{2}$ and $5 \% \mathrm{CO}_{2}$. This was considered Day 1 of culture. On Day 5 cleaved embryos were scored for cell number and transferred to fresh SOF medium. The embryonic development was assessed on Day 8.

\section{RESULTS}

\section{The Expression of Leptin Ligand, ObR-L, ObR-S, and ObR-T in Oocytes and Cumulus Cells}

Primers used to amplify the long isoform (ObR-L) and one of the short isoforms (ObR-S, designated ObR-a in rat and mouse) of the leptin receptor were designed whereby the unique sequences at the $3{ }^{\prime}$-sites of these isoforms were exploited. Expression of leptin and ObR-L was studied in cDNA samples from denuded oocytes and their corresponding cumulus cells by qualitative RTPCR after 0,7 , and $23 \mathrm{hr}$ of culture. As shown in Figure 1, mRNA for leptin ligand was present in denuded oocytes during all stages of nuclear maturation but not in the corresponding cumulus cells. Expression of the long isoform of the leptin receptor was detected exclusively in the cumulus cells of COCs after 7 and $23 \mathrm{hr}$ of maturation (Fig. 1) indicating an upregulation of this isoform during maturation.

Quantitative RT-PCR was performed to analyze the expression levels of ObR-S and of all the isoforms of the leptin receptor combined (ObR-T) in denuded oocytes and their corresponding cumulus cells after 0,7 , and $23 \mathrm{hr}$ of in vitro maturation. The ObR-T specific primers were designed on the sequence coding for the extracellular part of the receptor which is present in all receptor isoforms. For normalization of the expression levels, a set of genes with low variability in their expression levels in the experimental system being studied were identified by use of geNORM (Vandesompele et al., 2002). Therefore, of six reference genes ( $\beta$ Actin, GAPDH, Ubiquitin, rRNA, PGK, and RPL15), the expression levels were established by QRT-PCR in all experimental cDNA samples and the geNorm tool was used to identify the most stably expressed set of genes amongst the six candidate genes. Analysis of the starting quantities determined gene expression stability over the different stages of maturation, and resulted

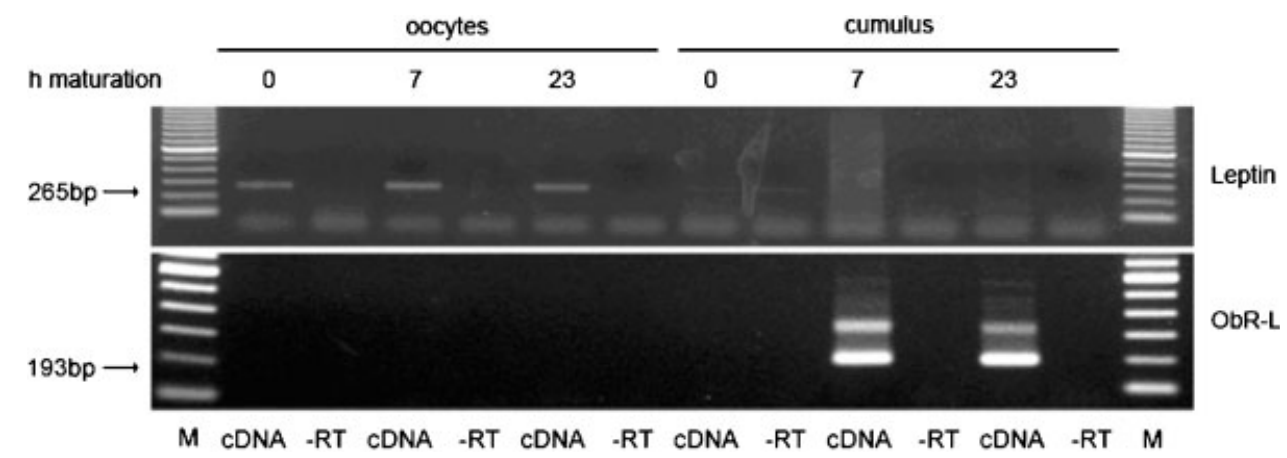

Fig. 1. Expression of Leptin and ObR-Lin oocytes and cumulus cells after 0, 7, and $23 \mathrm{hr}$ of maturation as detected by RT-PCR. $\mathrm{M}=100$ bp DNA marker. 
in gene expression stability values $M$ for each gene, whereby stepwise exclusion of unstable genes and subsequent recalculation of the average M-values resulted in a ranking of the genes based on their Mvalues with the two most stable genes leading the ranking. This stepwise elimination of the least stable genes revealed that the genes with the highest expression stability over the different meiotic stages in oocytes were Ubiquitin, GAPDH, and ß-Actin whereas PGK, Ubiquitin, and RPL15 were the most stably expressed genes in cumulus cells throughout maturation (Fig. 2).

Therefore, the geometric mean of the expression levels of Ubiquitin, GAPDH, and B-Actin was used to calculate the Normalization Factors for normalizing the starting quantities of ObR-T and ObR-S in oocytes and the geometric mean of PGK, Ubiquitin, and RPL15 was used to normalize the starting quantities in cDNA samples originating from cumulus cells.

The normalized expression levels of ObR-T and ObR-S in oocytes during maturation did not change (Fig. 3A,C). Conversely, in cumulus cells there was a 10 -fold increase in the expression level of ObR-S after $7 \mathrm{hr}$ of maturation (Fig. 3D), and the expression level of ObR-T accrued considerably throughout maturation (Fig. 3B). Amplification of the $-\mathrm{RT}$ blanks with gene specific primers did not result in measurable amounts of product.

\section{Phosphorylation of MAPK and STAT3 in COCs During Oocyte Maturation}

Since the short isoform of the leptin receptor can signal through the MAPK pathway and the long isoform is capable of signaling through both the STAT3 and the MAPK pathways, we investigated whether leptin can activate either of these pathways during oocyte maturation. After 0, 7, and $23 \mathrm{hr}$ of maturation COCs were incubated for $20 \mathrm{~min}$ with or without leptin $(100 \mathrm{ng} / \mathrm{ml})$. Lysates of the COCs were immunoblotted with antibodies against phosphorylated MAPK, phosphorylated
STAT3, and B-Actin, whereby MAPK appeared as a doublet at 44 and $42 \mathrm{kDa}$ representing ERK1 and ERK2. At the chosen time points, the phosphorylated forms of MAPK and STAT3 were already present in COCs and challenge of the COCs for 20 min with leptin did not result in a measurable increase of phosphorylated STAT3 or MAPK proteins. Significantly more phosphorylated ERK1 and ERK2 was however detected after $23 \mathrm{hr}$ of maturation (Fig. 4).

\section{Presence of Leptin During Maturation Does Not Affect Resumption of Meiosis But Accelerates Progression of Nuclear Maturation}

In the bovine, $50 \%$ of the oocytes cultured as complex with cumulus and parietal granulosa cells (COCGs) is still at the GV stage after $23 \mathrm{hr}$ of culture, where oocytes from COCs mature up to the M-II stage (van Tol et al., 1996). To determine whether leptin plays a role in resumption of meiosis, COCGs were cultured in the presence or absence of leptin $(1,000 \mathrm{ng} / \mathrm{ml})$, whereafter the nuclear status was assessed. After $23 \mathrm{hr}$ of culture there was no significant difference in the percentage of oocytes that underwent GV break down nor in the proportion of oocytes that matured up to the M-I or M-II stage after resumption of meiosis (Fig. 5A).

It has been reported that after $7 \mathrm{hr}$ of maturation in vitro, GVBD has occurred in $50 \%$ of the bovine oocytes (Sirard et al., 1989) and that between 16 and $20 \mathrm{hr}$ of maturation the percentage of oocytes that matured up to the M-II stage increased from $36 \%$ to $69 \%$ (Izadyar et al., 1998). To study whether leptin can influence the progression of nuclear maturation, COCs were cultured for 7,17 , and $23 \mathrm{hr}$ in the presence or absence of leptin and the nuclear status was assessed as described above. The nuclear status of the oocytes at 7 and $23 \mathrm{hr}$ of maturation was not influenced by the presence of leptin. (Fig. 5B,D). However, after $17 \mathrm{hr}$ of maturation the percentage of oocytes still in the M-I stage was significantly lower in the group treated with $1,000 \mathrm{ng} /$
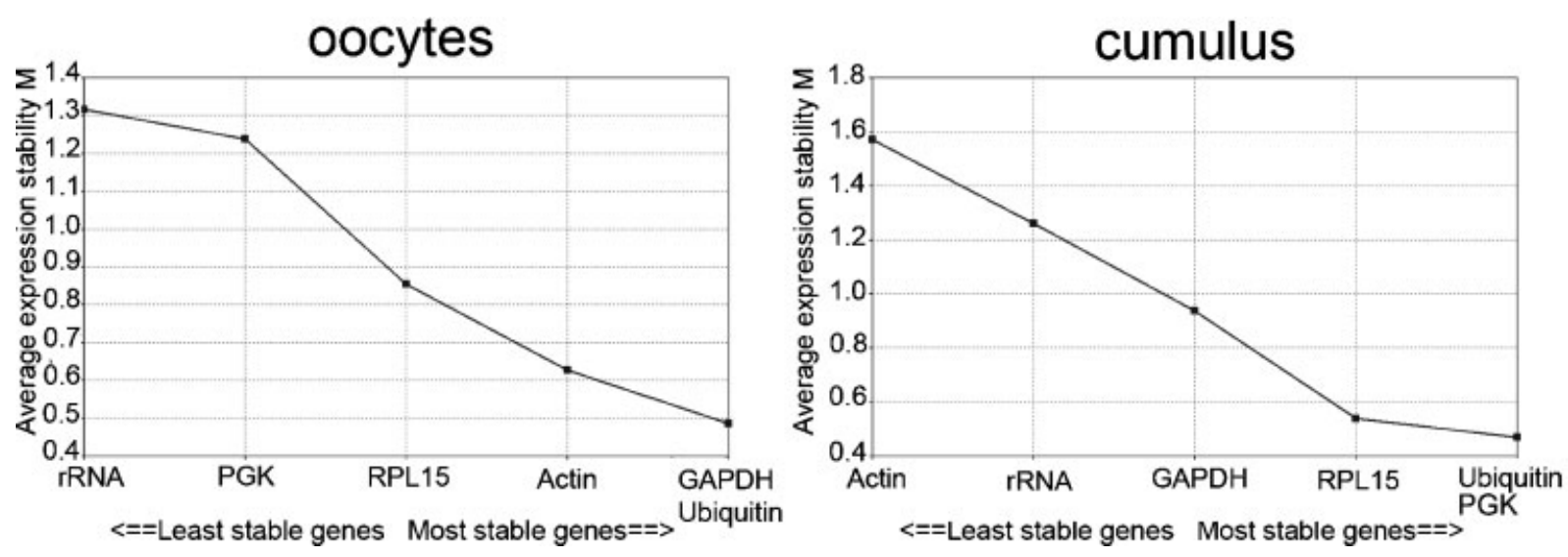

Fig. 2. Average expression stability values $M$ after stepwise exclusion of the least stable gene. Starting from the least stable gene at the left, the genes are ranked according to increasing expression stability, ending with GAPDH and Ubiquitin in oocytes and Ubiquitin and PGK in cumulus cells as the two most stable genes. 


\section{A oocytes}

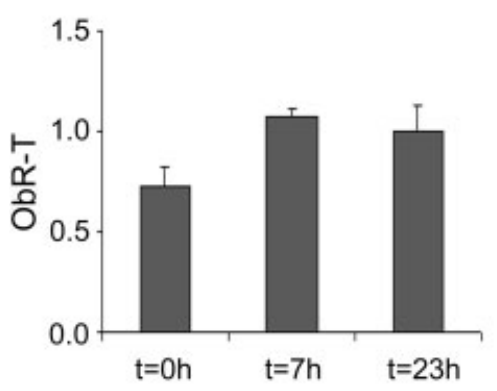

c oocytes

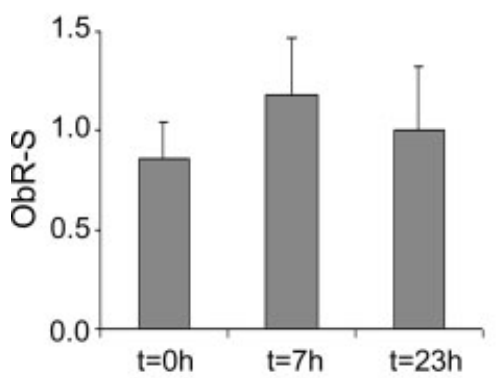

B cumulus

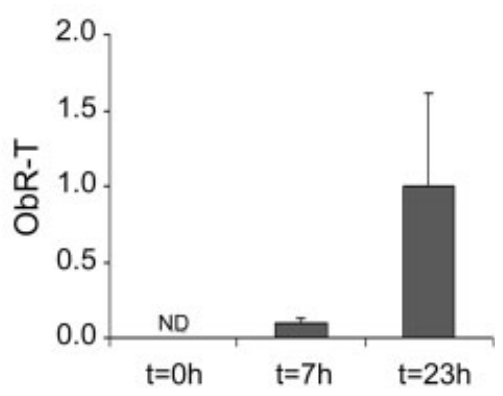

D

\section{cumulus}

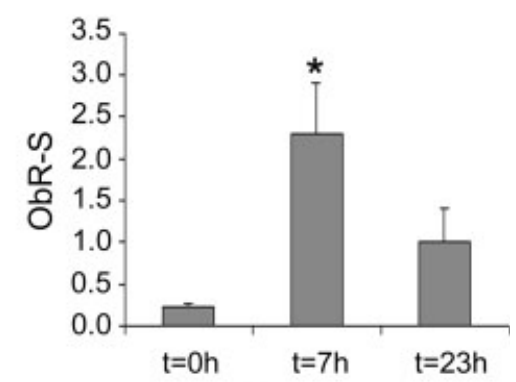

Fig. 3. Relative normalized expression levels of ObR-T and ObR-S during in vitro maturation on the indicated time periods in oocytes $(\mathbf{A}, \mathbf{C})$ and cumulus cells $(\mathbf{B}, \mathbf{D})$. Normalization factors were calculated by use of the geNORM tool. Results are means \pm SEM of three pools of denuded oocytes or cumulus cells, whereby the expression levels at $\mathrm{t}=23 \mathrm{hr}$ are set at 1 . Significant differences from the control group $(0 \mathrm{ng} / \mathrm{ml}$ leptin) are indicated by an asterisk $(P<0.05$, Student's $t$-test $) . \mathrm{ND}=$ below detection level.

$\mathrm{ml}$ leptin compared to the control group $(P<0.05$, Fig. 5C).

\section{Presence of Leptin During Maturation Enhances Developmental Capacity of the Oocyte}

Next we determined if the presence of leptin during maturation influences the developmental capacity of oocytes. There was no influence of leptin supplementation on the cleavage rate after fertilization, however addition of $1,000 \mathrm{ng} / \mathrm{ml}$ leptin to the maturation medium

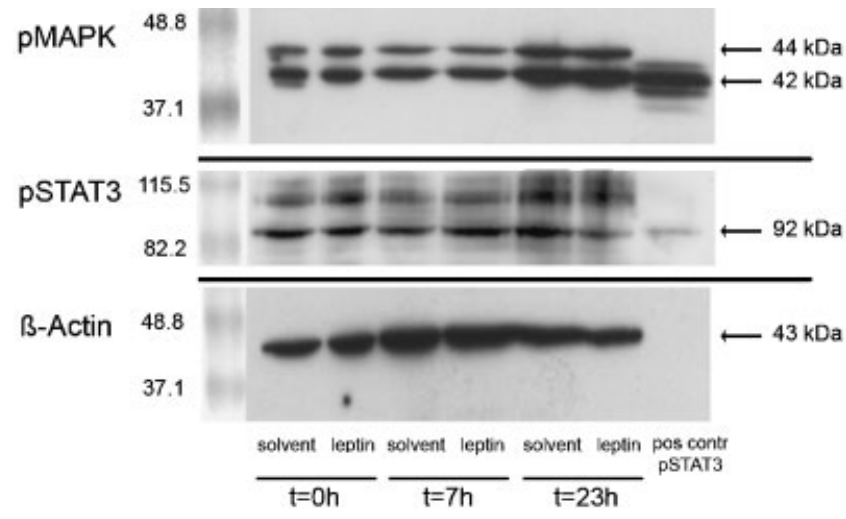

Fig. 4. Immunoreactive analysis of phosphorylated MAPK and STAT3 proteins in bovine COCs after 0,7 , and $23 \mathrm{hr}$ of maturation. COCs were challenged with $100 \mathrm{ng} / \mathrm{ml}$ leptin for $20 \mathrm{~min}$. resulted in a significant $(P<0.001)$ increase in the proportion of cleaved zygotes that had developed up to the 8 cell stage at Day 5 of culture (Fig. 6A,B). Furthermore, this leptin concentration resulted in more $(P<0.05)$ oocytes that developed to the blastocyst stage as determined on Day 8 of culture (Fig. 6C). Treatment of oocytes with 10 or $100 \mathrm{ng} / \mathrm{ml}$ leptin did not affect their developmental capacity.

\section{DISCUSSION}

In order to determine the role of leptin in bovine oocyte maturation, the expression of leptin and leptin receptor isoforms in oocytes and cumulus cells during oocyte maturation in vitro and the effect of leptin on nuclear and cytoplasmic maturation was examined.

To analyze expression levels of leptin ligand and ObRL, qualitative RT-PCR was applied on cDNA samples from denuded oocytes and their corresponding cumulus cells. The results show that leptin ligand is expressed in the oocyte, but not in the corresponding cumulus cells, during all stages of nuclear maturation and to our knowledge this is the first report about leptin mRNA expression in bovine oocytes. During oocyte maturation in vivo, COCs are surrounded by follicular fluid with a leptin concentration of about $5 \mathrm{ng} / \mathrm{ml}$ (Dayi et al., 2005). This observation, together with the low expression level of leptin mRNA in oocytes, point to a minor role of these 
A

COCG

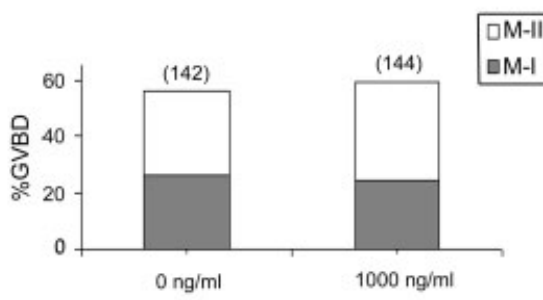

C

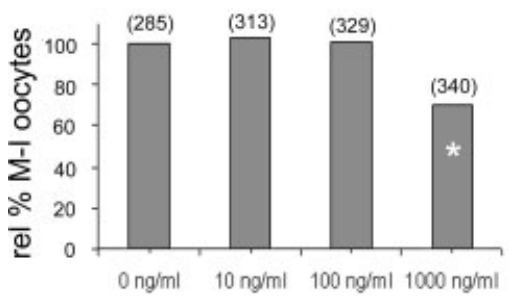

B $\operatorname{coc} 7 \mathrm{~h}$

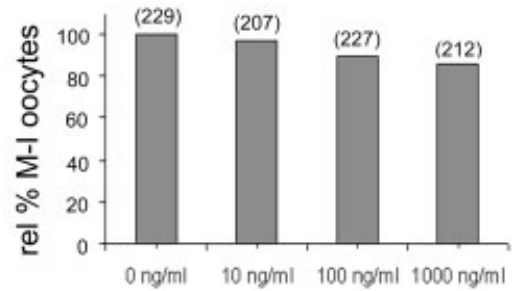

D $\quad \operatorname{coc} 23 \mathrm{~h}$

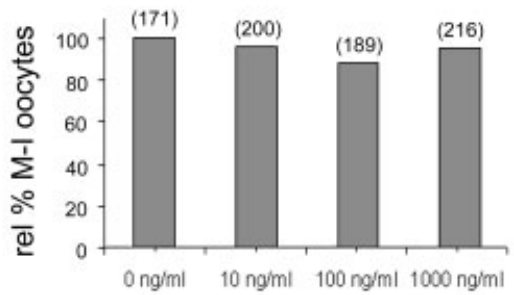

Fig. 5. Leptin does not affect resumption, but accelerates progression, of oocyte nuclear maturation. Bovine oocytes were cultured as COCG for $23 \mathrm{hr}(\mathbf{A})$ with or without $1,000 \mathrm{ng} / \mathrm{ml}$ leptin or as COC for $7 \mathrm{hr}$ (B), $17 \mathrm{hr}(\mathbf{C})$, or $23 \mathrm{hr}(\mathbf{D})$ with 0, 10, 100, and 1,000 ng/ml leptin. In graph B-D, the proportion of oocytes at $\mathrm{M}$-I in the control group $(0 \mathrm{ng} / \mathrm{ml}$ leptin) is set at $100 \%$. In the leptin-treated groups, the relative percentage of oocytes in the M-I stage is calculated on basis of the control group. Total number of oocytes between brackets. Significant differences from the control group are indicated by an asterisk $(P<0.05$, analysis of logistic regression).

A

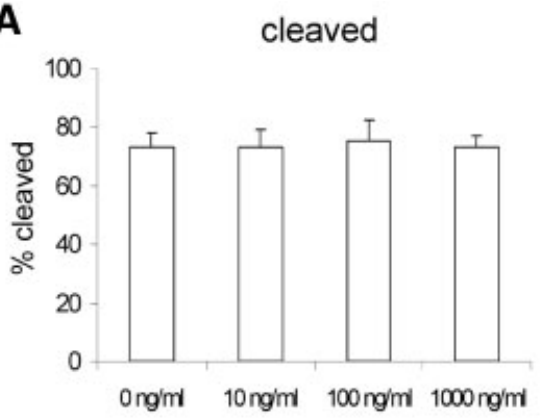

C

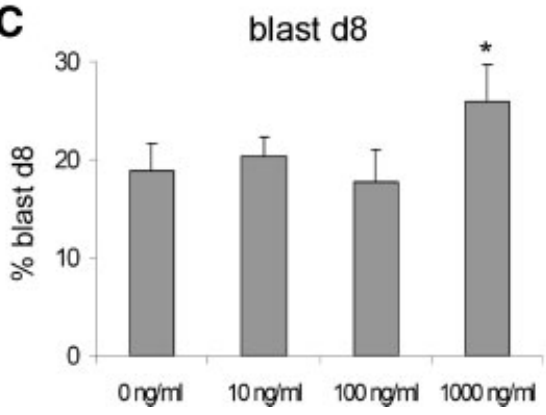

B

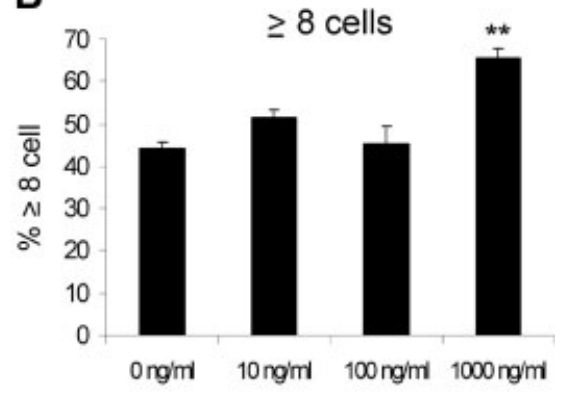

Fig. 6. Effect of leptin on cleavage rate $(\mathbf{A})$ and cell number on Day 5 (B) of embryo culture and on blastocyst formation on Day 8 of culture $(\mathbf{C})$. Cleavage rate and blastocyst formation were calculated on basis of the number of fertilized oocytes on Day 1. Percentage of zygotes consisting of eight or more cells was calculated on basis of the total amount of cleaved zygotes at Day 5. Results are means \pm SEM of three replicates using $72-100$ COCs per treatment. Significant differences from the control group $(0 \mathrm{ng} / \mathrm{ml} \mathrm{leptin})$ are indicated by one $(P<0.05)$ or two asterisks $(P<0.001$, analysis of logistic regression). 
oocyte-derived leptin transcripts in maturation. Oocytes contain large populations of mRNA which are important to sustain embryonic development up to the stage of maternal-embryonic transition, which in cattle occurs at the 8-16-cell stage. Possibly, the transcripts in bovine oocytes belong to this pool of indispensable gene products although studies in both mouse (Kawamura et al., 2002) and human (Cervero et al., 2004) report the absence of leptin mRNA until the blastocyst stage. Furthermore, the expression of ObR-L transcripts after one round of amplification was detected exclusively in cumulus cells after 7 and $23 \mathrm{hr}$ of maturation (data not shown) and nested PCR confirmed this finding.

The data presented in this study concerning expression of mRNA transcripts of leptin and ObR-L in oocytes is in agreement with findings in porcine oocytes (Craig et al., 2004) but the absence of ObR-L in oocytes is in contrast with the finding in mice where a role of leptin during oocyte maturation by activating the STAT3 signal transduction pathway has been suggested by Matsuoka et al. (1999). This discrepancy points to a species-specific mode of action of the leptin system in oocyte maturation.

In most studies concerning the function of leptin on oocyte maturation, the focus is on the oocyte itself but not on the surrounding cumulus cells which play a critical role in oocyte maturation by releasing and mediating signals to oocytes (Tanghe et al., 2002). Only recently, Paula-Lopes et al. (2007) reported that the presence of leptin in maturation medium resulted both in promotion of the developmental capacity of bovine oocytes through a cumulus cell-dependent mechanism, and in a decrease in the incidence of apoptosis in cumulus cells. Several studies concerning apoptosis in cumulus cells during meiotic maturation show that an increased incidence of cumulus cell apoptosis during meiotic maturation is correlated with decreased developmental competence of the oocyte (Lee et al., 2001; Ikeda et al., 2003; Yuan et al., 2005). The upregulation in the expression of ObR-L in cumulus cells in the first $7 \mathrm{hr}$ of oocyte maturation indicates a cumulus cell-mediated role of leptin in this event, possibly by preventing the occurrence of apoptosis in the cumulus cells.

Although studies concerning the expression stability of reference genes show that expression of these genes can vary considerably in different cell types or in different experimental conditions (Bustin, 2000; Warrington et al., 2000), internal control genes are most frequently used to normalize mRNA fractions without proper validation of their presumed stability of expression. In the here presented study, analysis of the transcription stability of six reference genes in oocytes and cumulus cells revealed that GAPDH and Ubiquitin were the most stably expressed genes in oocytes during all maturational stages. Furthermore, PGK was found to be the least stably expressed gene which is in agreement with a study from Bettegowda et al. (2006) who found a strong decrease in PGK transcripts during meiosis. In contrast to the finding in oocytes, in cumulus cells PGK was one of the most stably expressed genes which demonstrates the necessity of thorough evaluation of reference genes in different tissue types.

In this study, it is demonstrated that ObR-T and ObR$\mathrm{S}$ transcripts are present in bovine oocytes, and that these transcripts do not show significant changes in expression levels throughout maturation. In porcine, leptin mRNA is expressed in the oviduct and the presence of leptin receptors has been identified in all stages of embryonic development. Moreover the presence of leptin in the embryo culture medium significantly increased the proportion of cleaved embryos (Craig et al., 2005). The steady expression levels of leptin receptor isoforms in oocytes during maturation therefore imply that these transcripts are stored to support early embryonic development rather than having a function in oocyte maturation.

Activation of ObR-S can lead to Janus kinase and MAPK activation, but the function of ObR-S signaling is unclear. Nevertheless, the temporal upregulation of ObR-S expression in cumulus cells in the first $7 \mathrm{hr}$ of maturation points to a cumulus cell-mediated role for leptin in oocyte maturation via this receptor isoform.

The expression level of ObR-T in cumulus cells at $\mathrm{t}=$ 0 could not be detected while after 7 and $23 \mathrm{hr}$ of maturation the amount of ObR-T mRNA could be quantified in all samples. Because the normalization factors of all samples were in the same order of magnitude, the amount of ObR-T transcripts in cumulus cells increased considerably throughout oocyte maturation. As the expression levels of ObR-L were relatively low and the expression levels of ObR-S did not increase between 7 and $23 \mathrm{hr}$ of culture, it is improbable that these isoforms contributed to the increase in expression of ObR-T in cumulus cells during oocyte maturation. Therefore, this upregulation in leptin receptor mRNA must be attributed to the distinct short isoforms whose function is not yet elucidated, or to the soluble receptor isoform which is thought to be a binding protein for leptin.

Although levels of phosphorylated MAPK increased between 7 and $23 \mathrm{hr}$ of maturation, presence of leptin during maturation did not result in a measurable increase of phosphorylated STAT3 or MAPK proteins. These experiments are conducted on cumulus oocyte complexes and further experiments have to be performed on oocytes and cumulus cells separately, since a highly activated protein in cumulus cells may have masked an increase in phosphorylation in oocytes and vice versa.

Previous studies showed that leptin directly controls the secretory activity of human granulosa cells (Brannian et al., 1999; Sirotkin et al., 2005), furthermore culture of follicles in the presence of leptin increased the proportion of mouse oocytes that underwent GV breakdown (Ryan et al., 2002). This indicates a role for leptin in controlling maturation in the oocyte through follicular cells, but in our study leptin, up to $1,000 \mathrm{ng} / \mathrm{ml}$, could not overrule the meiotic inhibitory effect of granulosa 


\section{H.T.A. VAN TOL ET AL.}

cells. Experiments with 10 and $100 \mathrm{ng} / \mathrm{ml}$ led to the same result (data not shown).

In previous studies, it is described that $10 \mathrm{ng} / \mathrm{ml} \mathrm{leptin}$ promotes meiotic progression as indicated by an increase in the proportion of oocytes with extruded first polar body after maturation (Craig et al., 2004; Paula-Lopes et al., 2007). However, increased concentration of leptin in the culture medium $(100 \mathrm{ng} / \mathrm{ml}$ in bovine; $1,000 \mathrm{ng} / \mathrm{ml}$ in porcine) failed to stimulate oocyte maturation, indicating that the effect is concentration dependent. Although we did not determine the extrusion of the first polar body, analysis of the different nuclear stages of oocytes after $23 \mathrm{hr}$ of maturation showed no significant influence on the proportion of oocytes that matured up to the M-II stage by any of the leptin concentrations used. Moreover, as determined after $7 \mathrm{hr}$ of maturation none of the leptin concentrations influenced the occurrence of GVBD. However after GVBD, the progression of meiosis was stimulated by the presence of $1,000 \mathrm{ng} / \mathrm{ml}$ leptin as indicated by a decreased proportion of oocytes that was in the M-I stage after $17 \mathrm{hr}$ of maturation. Besides a beneficial effect on the progression of maturation, it is also demonstrated that the presence of $1,000 \mathrm{ng} / \mathrm{ml}$ leptin during maturation improved the developmental capacity of the oocytes. This beneficial effect of leptin on embryo development is probably attributed by an effect on the cytoplasmic maturation since the proportion of M-II oocytes after $23 \mathrm{hr}$ of maturation, the time point at which IVF was performed, was not affected.

Although after fertilization, the cleavage rates were not influenced by leptin; the proportion of zygotes that developed up to the 8-cell stage after 5 days of culture was strikingly increased indicating that the presence of leptin during oocyte maturation enhances the developmental capacity of oocytes by supporting embryonic development up to the transition of maternal to embryonic genome transcription. Furthermore, this relatively high concentration resulted in an increased proportion of oocytes that developed to the blastocyst stage on Day 8 of embryo culture which is not in agreement with findings in previous studies in bovine and porcine oocytes (Craig et al., 2004; Paula-Lopes et al., 2006), wherein much lower leptin concentrations $(10 \mathrm{ng} / \mathrm{ml})$ in the maturation medium resulted in increased developmental competence of the oocytes. The experiments described in our study concerning the effect of leptin on nuclear and cytoplasmic maturation were performed in the absence of any protein other than leptin. In the aforementioned studies the culture medium contained FSH that could have enhanced the sensitivity of COCs for leptin.

In conclusion, in this study, we demonstrate the expression of leptin ligand and the short isoforms of the leptin receptor in bovine oocytes and an upregulation of ObR-S and ObR-L in cumulus cells during the first $7 \mathrm{hr}$ of maturation. Furthermore, it is demonstrated that leptin enhances the progression of nuclear maturation and, present exclusively during IVM, is capable of increasing the proportion of oocytes reaching the blastocyst stage. It is concluded that leptin plays a cumulus cell-mediated role in the improvement of cytoplasmic maturation.

\section{ACKNOWLEDGMENTS}

The assistance of the laboratory members during puncture sessions is acknowledged. We thank Dr. R. Hanssen, Organon, Oss, The Netherlands, for the kind donation of recombinant FSH and Mr. F van Kooij and co-workers for supplying the ovaries.

\section{REFERENCES}

Antczak M, van Blerkom J. 1997. Oocyte influences on early development: The regulatory proteins leptin and STAT3 are polarized in mouse and human oocytes and differentially distributed within the cells of the preimplantation stage embryo. Mol Hum Reprod 3:10671086.

Barash IA, Cheung CC, Weigle DS, Ren H, Kabigting EB, Kuijper JL, Clifton DK, Steiner RA. 1996. Leptin is a metabolic signal to the reproductive system. Endocrinology 137:3144-3147.

Bates SH, Stearns WH, Dundon TA, Schubert M, Tso AW, Wang Y, Banks AS, Lavery HJ, Haq AK, Maratos-Flier E, Neel BG, Schwartz MW, Myers MG Jr. 2003. STAT3 signalling is required for leptin regulation of energy balance but not reproduction. Nature 421:856859.

Bettegowda A, Patel OV, Ireland JJ, Smith GW. 2006. Quantitative analysis of messenger RNA abundance for ribosomal protein L-15, cyclophilin-A, phosphoglycerokinase, beta-glucuronidase, glyceraldehyde 3-phosphate dehydrogenase, beta-actin, and histone H2A during bovine oocyte maturation and early embryogenesis in vitro. Mol Reprod Dev 73:267-278.

Bjorbaek C, Uotani S, da Silva B, Flier JS. 1997. Divergent signaling capacities of the long and short isoforms of the leptin receptor. J Biol Chem 272:32686-32695.

Boelhauve M, Sinowatz F, Wolf E, Paula-Lopes FF. 2005. Maturation of bovine oocytes in the presence of leptin improves development and reduces apoptosis of in vitro-produced blastocysts. Biol Reprod 73:737-744.

Brannian JD, Zhao Y, McElroy M. 1999. Leptin inhibits gonadotrophin-stimulated granulosa cell progesterone production by antagonizing insulin action. Hum Reprod 14:1445-1448.

Bustin SA. 2000. Absolute quantification of mRNA using real-time reverse transcription polymerase chain reaction assays. $\mathrm{J} \mathrm{Mol}$ Endocrinol 25:169-193.

Cervero A, Horcajadas JA, Martín J, Pellicer A, Simón C. 2004. The leptin system during human endometrial receptivity and preimplantation. J Clin Endocrinol Metab 89:2442-2451.

Chehab FF, Lim ME, Lu R. 1996. Correction of the sterility defect in homozygous obese female mice by treatment with the human recombinant leptin. Nat Genet 12:318-320.

Cioffi JA, Van Blerkom J, Antczak M, Shafer A, Wittmer S, Snodgrass HR. 1997. The expression of leptin and its receptors in pre-ovulatory human follicles. Mol Hum Reprod 3:467-472.

Craig J, Zhu H, Dyce PW, Petrik J, Li J. 2004. Leptin enhances oocyte nuclear and cytoplasmic maturation via the mitogen-activated protein kinase pathway. Endocrinology 145:5355-5363.

Craig JA, Zhu H, Dyce PW, Wen L, Li J. 2005. Leptin enhances porcine preimplantation embryo development in vitro. Mol Cell Endocrinol 229:141-147.

Dayi A, Bediz CS, Musal B, Yilmaz O, Comlekci A, Celiloglu M, Cimrin D. 2005. Comparison of leptin levels in serum and follicular fluid during the oestrous cycle in cows. Acta Vet Hung 53:457-467.

Ikeda S, Imai H, Yamada M. 2003. Apoptosis in cumulus cells during in vitro maturation of bovine cumulus-enclosed oocytes. Reproduction 125:369-376.

Izadyar F, Colenbrander B, Bevers MM. 1996. In vitro maturation of bovine oocytes in the presence of growth hormone accelerates nuclear maturation and promotes subsequent embryonic development. Mol Reprod Dev 45:372-377.

Izadyar F, Zeinstra E, Bevers MM. 1998. Follicle-stimulating hormone and growth hormone act differently on nuclear maturation while 
both enhance developmental competence of in vitro matured bovine oocytes. Mol Reprod Dev 51:339-345.

Kawamura K, Sato N, Fukuda J, Kodama H, Kumagal J, Tanikawa H, Nakamura A, Tanaka T. 2002. Leptin promotes the development of mouse preimplantation embryos in vitro. Endocrinology 143:19221931

Lee GH, Proenca R, Montez JM, Carroll KM, Darvishzadeh JG, Lee JI, Friedman JM. 1996. Abnormal splicing of the leptin receptor in diabetic mice. Nature 379:632-635.

Lee KS, Joo BS, Na YJ, Yoon MS, Choi OH, Kim WW. 2001. Cumulus cells apoptosis as an indicator to predict the quality of oocytes and the outcome of IVF-ET. J Assist Reprod Genet 18:490-498.

Lin J, Barb CR, Matteri RL, Kraeling RR, Chen X, Meinersmann RJ, Rampacek GB. 2000. Long form leptin receptor mRNA expression in the brain, pituitary, and other tissues in the pig. Domest Anim Endocrinol 19:53-61.

Matsuoka T, Tahara M, Yokoi T, Masumoto N, Takeda T, Yamaguchi M, Tasaka K, Kurachi H, Murata Y. 1999. Tyrosine phosphorylation of STAT3 by leptin through leptin receptor in mouse metaphase 2 stage oocyte. Biochem Biophys Res Commun 256:480-484.

Parrish JJ, Susko-Parrish J, Winer MA, First NL. 1988. Capacitation of bovine sperm by heparin. Biol Reprod 38:1171-1180.

Paula-Lopes FF, Boelhauve M, Habermann FA, Sinowatz F, Wolf E. 2007. Leptin promotes meiotic progression and developmental capacity of bovine oocytes via cumulus cell-independent and dependent mechanisms. Biol Reprod 76:532-541.

Ruiz-Cortes ZT, Men T, Palin MF, Downey BR, Lacroix DA, Murphy BD. 2000. Porcine leptin receptor: Molecular structure and expression in the ovary. Mol Reprod Dev 56:465-474.

Ryan NK, Woodhouse CM, Van der Hoek KH, Gilchrist RB, Armstrong DT, Norman RJ. 2002. Expression of leptin and its receptor in the murine ovary: Possible role in the regulation of oocyte maturation. Biol Reprod 66:1548-1554.

Sirard MA, Florman HM, Leibfried-Rutledge ML, Barnes FL, Sims ML, First NL. 1989. Timing of nuclear progression and protein synthesis necessary for meiotic maturation of bovine oocytes. Biol Reprod 40:1257-1263.
Sirotkin AV, Mlyncek M, Kotwica J, Makarevich AV, Florkovicova I, Hetenyi L. 2005. Leptin directly controls secretory activity of human ovarian granulosa cells: Possible inter-relationship with the IGF/ IGFBP system. Horm Res 64:198-202.

Spicer LJ, Francisco CC. 1998. Adipose obese gene product, leptin inhibits bovine ovarian thecal cell steroidogenesis. Biol Reprod 58:207-212.

Tanghe S, Van Soom A, Nauwynck H, Coryn M, de Kruif A. 2002. Minireview: Functions of the cumulus oophorus during oocyte maturation, ovulation, and fertilization. Mol Reprod Dev 61:414424.

Tartaglia LA. 1997. The leptin receptor. J Biol Chem 272:6093-6096. van Tol HT, van Eijk MJ, Mummery CL, van den Hurk R, Bevers MM. 1996. Influence of FSH and hCG on the resumption of meiosis of bovine oocytes surrounded by cumulus cells connected to membrana granulosa. Mol Reprod Dev 45:218-224.

Vandesompele J, De Preter K, Pattyn F, Poppe B, Van Roy N, De Paepe A, Speleman F. 2002. Accurate normalization of real-time quantitative RT-PCR data by geometric averaging of multiple internal control genes. Genome Biol 3: (research 0034.1-0034.11).

Warrington JA, Nair A, Mahadevappa M, Tsyganskaya M. 2000. Comparison of human adult and fetal expression and identification of 535 housekeeping/maintenance genes. Physiol Genomics 2:143147.

Yang G, Ge H, Boucher A, Yu X, Li C. 2004. Modulation of direct leptin signaling by soluble leptin receptor. Mol Endocrinol 18:1354-1362.

Yuan YQ, Van Soom A, Leroy JL, Dewulf J, Van Zeveren A, de Kruif A, Peelman LJ. 2005. Apoptosis in cumulus cells, but not in oocytes, may influence bovine embryonic developmental competence. Theriogenology 63:2147-2163.

Zamorano PL, Mahesh VB, De Sevilla LM, Chorich LP, Bhat GK, Brann DW. 1997. Expression and localization of the leptin receptor in endocrine and neuroendocrine tissues of the rat. Neuroendocrinology 65:223-228.

Zhang Y, Proenca R, Maffei M, Barone M, Leopold L, Friedman JM. 1994. Positional cloning of the mouse obese gene and its human homologue. Nature 372:425-432. 